Data relating to aggregate anonymised tissue and other samples-These will not normally be considered to be personal information relating to a particular patient, and publication of research findings connected with such samples does not require patient consent.

Genetic pedigrees-These represent a special problem. The committee is preparing a paper on this.

Medical error-One particularly intriguing type of case is medical error. Consider, for example, a recent published case report on "wrong side" surgery. ${ }^{11}$ The surgeon is at greater risk than the patient in relation to publication of this information. Publications about error should be encouraged as they are core to improvements in patient safety in both relation to analysis of root causes and engendering a culture of openness about error. If a patient refused consent to publish, perhaps because of anger at the physician, should that preclude publication? If you might publish even if the patient refused, should you even ask permission?

\section{Conclusions}

The objective in revising $B M J$ policy on consent to the publication of patient information was to ensure the protection of patient confidentiality while at the same time seeking to facilitate the serious communication of medical information. In clinical practice confidentiality is not an absolute principle but admits of exceptions-for example, the duty to warn-and it should therefore come as no surprise that confidentiality is not absolute in editorial practice either. The policy set out above should afford adequate protection for confidentiality without making informative exchanges impossible. Our position recognises that ethics is rarely about absolutes: context matters, and judgment is essential.

\section{Summary points}

Publication of data arising from the doctorpatient relationship normally requires consent

In a few circumstances publication can be justified without consent

The $B M J$ has revised its policy to clarify these circumstances

The current members of the $B M J$ Ethics Committee are Iona Heath (chair), Andrew Lawson, Asad Raja, Peter Singer, Ann Sommerville, Jeffrey Tobias, Derick Wade, Elizabeth Wager, and Tom Wilkie. Richard Smith also attended meetings. Alexander McCall Smith chaired the committee from 2000 to 2003 and drafted this article for the committee with PS. We thank the $B M$ J editors who participated in the development of this policy, especially those who pilot tested it. Rachel Fetches provided valuable help to the committee in preparing this article.

PAS is a distinguished investigator of the Canadian Institutes of Health Research.

Competing interests: None declared.

1 International Committee of Medical Journal Editors. Uniform requirement. for manuscripts submitted to biomedical journals. Privacy and confidentiality. www.icmje.org/index.html\#privacy (accessed 30 Mar 2004).

2 General Medical Council. Confidentiality: protecting and providing information. Publishing case studies. www.gmc-uk.org/standards confidentiality_faq.htm (accessed 21 May 2004).

Smith R. Informed consent: edging forwards (and backwards). BMJ 1998;316:949-51.

Kerr D. A pyrrhic victory. BMJ 2002;325:1011.

5 Palimar P. Strangers in the night. BMJ 2002;325:1104

Andrade C. Straight from the patient's mouth. BMJ 2002;325:1169.

Andrade C. Straight from the patient's mouth. BMJ 2002;325:1169.
Collins I. But the greatest of these is charity. BMJ 2002;325:1358.

Shah S. A piece of my mind: five miles from tomorrow. JAMA 2000 284:1897-8

9 Josefson D. JAMA falls foul of fabricated suicide story. BMJ 2001;323:472.

10 Gottlieb S. Methylphenidate works by increasing dopamine levels. $B M J$ 2001;322:259.

11 Bernstein M. Wrong side surgery: systems for prevention. Can J Surg 2003;46:144-6

(Accepted 2 June 2004)

\title{
Barbara's bowel
}

Four inches of snow and my hilltop home is cut off, so, one snowy day, I swapped a radiological session at my base hospital for a session at a local cottage hospital just two miles down the hill. No sooner had I set out to walk in boots and anorak, than a Landrover driven by a gentleman farmer stopped, and I was offered a lift. His passenger was my neighbour, Barbara, an elegant professional lady whose vitality and sophisticated charm guaranteed her popularity, particularly among the local gentry. As we inched down the icy Cotswold lane, I was pleased to learn that Barbara, conveniently for me, was also heading for the hospital to keep an appointment. Indeed, that is why she had enlisted the help of her friend with his four wheel drive vehicle. However, my pleasure quickly changed to disquiet when I learnt that Barbara was to have a barium enema, and I knew I would be the radiologist assigned to perform it.

We all prefer examinations to proceed with Germanic efficiency in sleek modern surroundings, particularly if the patient is a friend and the procedure a delicate one. But it wasn't like that. The local $x$ ray equipment was on its last legs, and the department was just about to be refitted and redecorated. Radiological reporting was carried out in the tiny radiographers' coffee room just beyond the toilet outside the $\mathrm{x}$ ray room, and dictation had to be quiet enough to be inaudible to the patient in the toilet next door. The environment was decrepit, and some examinations almost sordid. To add to the problem, Barbara had a lengthy, tortuous colon, and-despite turning, twisting, and compressing her-barium and air would not pass proximal to the hepatic flexure. Eventually, after a protracted and messy examination, I had to settle for suboptimal, single contrast views of the caecum.

The only comforting news that morning was that no other patient was able to get to the hospital. All had telephoned to cancel their appointment. Consequently, as Barbara left the department, I departed with her. Her farmer friend looked less than happy after the unexpected wait but, nevertheless, generously offered me a lift back up the hill. I returned to the comfort of the fireside, Barbara having been my only patient of the morning.

Barium enemas are no longer performed at the cottage hospital, and the radiology department has been refurbished with new equipment. From time to time, I see Barbara around the village. She is always charming and cheerful, but, having spent over an hour looking at her bowel, I find I can no longer look her in the eye.

Brian Witcombe consultant radiologist, Gloucestershire Royal Hospital, Gloucester 